\title{
Peningkatan Skill Productivity Bagi Pengrajin Batu Piring di Desa Sukowiryo Kecamatan Jelbuk Kabupaten Jember
}

\author{
Lilis Yuliati' ${ }^{1}$, Siti Komariyah ${ }^{2}$, Sudarsono ${ }^{3}$ \\ 1,2Fakultas Ekonomi dan Bisnis, ${ }^{3}$ Fakultas Keguruan dan Ilmu Pendidikan \\ Universitas Jember \\ Email: 1lilisyuliati.feb@unej.ac.id, 2sitikomariyah.feb@unej.ac.id, \\ darsono.ghj@gmail.com
}

\begin{abstract}
Plate stone handicraft products are one of the leading commodities and also potential for Sukowiryo Village, Jelbuk District, Jember Regency. Apart from being a superior commodity and village potential, plate stone handicraft products are also an export commodity. However, most of the plate stone handicraft production process in Sukowiryo Village still uses simple tools and manual processes. Therefore, the production process takes a longer time and the quality of the production is not standardized. The purpose of this PPK service activity is to provide real solutions to problems in the production process that connect by partners so that partners can increase skill productivity so that partners can carry out efficiency and can increase their production. The results of the KDP service activities were; 1) provide assistance to increase Skill Productivity by providing assistance with plate stone cutting machines according to partner needs. Build sewer and air reservoirs, and increase the partner's electric power to operate the plate stone cutting machine. 2) Partners can make time efficiency in the production process. 3) Partners can increase their productivity, 4) Partners can add 1 type of product diversification. 5) Carry out monitoring and evaluation after the program is implemented.
\end{abstract}

Keyword: Skill Productivity, Stone Plate, Eficiency

\section{Pendahuluan}

Kerajinan Batu Piring merupakan salah satu potensi yang ada Kecamatan Kalisat dan Jelbuk. Salah satu desa yang sangat potensi dengan batu piring adalah Desa Sukowiryo Kecamatan Jelbuk Kabupaten Jember. ${ }^{1}$ Kegiatan Produksi kerajinan batu piring lebih tepatnya banyak dilakukan

${ }^{1}$ Pemerintah Desa Sukowiryo Kecamatan Jelbuk Kabupaten Jember, 2020. 
oleh penduduk Dusun Krajan II Desa Sukowiryo. Dalam proses produksi kerajinan batu piring, bahan baku batunya tidak dihasilkan dari desa Sukowiryo sendiri melainkan diperoleh dari Kecamatan Kalisat, akan tetapi jaraknya justru lebih dekat dengan Desa Sukowiryo karena langsung berbatasan dengan kecamatan Kalisat, sehingga transportation cost bisa ditekan.

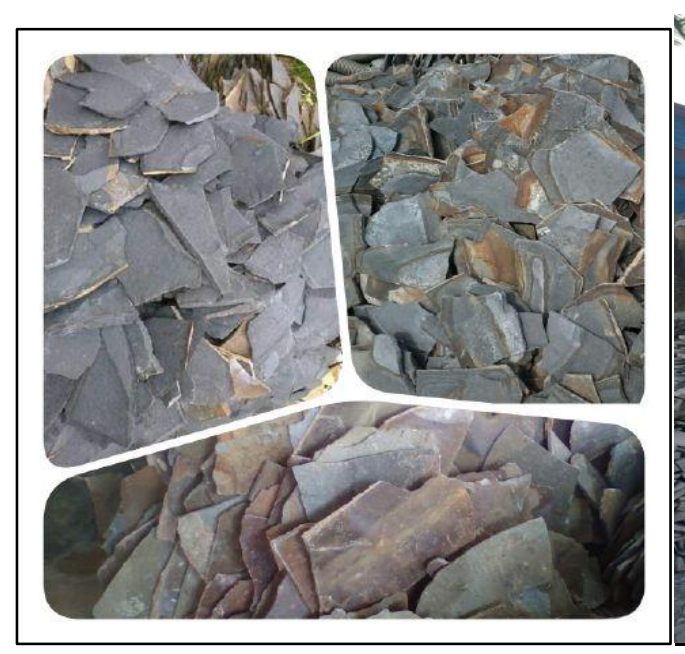

(a) Batu Piring yang Belum Diproses

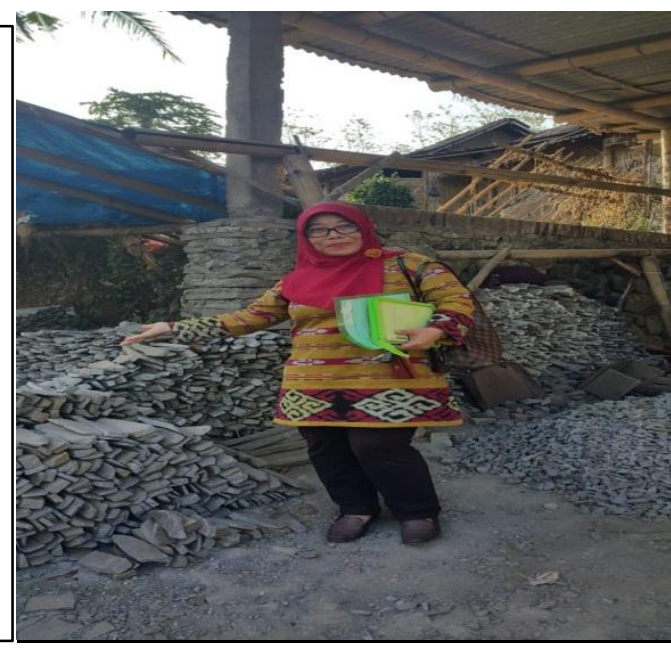

(b) ) Batu Piring yg Sudah Diproses Secara Manual Menggunakan Palu

\section{Gambar 1. Potensi Kerajinan Batu Piring Di Dusun Krajan Ii Desa Sukowiryo Kecamatan Jelbuk Kabupaten Jember (Sumber: Data Primer, 2020)}

Sebagaimana yang ditunjukkan oleh Gambar 1, Dusun Krajan II memiliki potensi yang besar pada poduk kerajinan batu piring, dan telah memiliki pangsa pasar yang luas, baik domestik maupun diekspor ke luar negeri. Jika ditinjau dari segi harga, batu piring memiliki berbagai variasi harga bergantung pada kualiatas, ukuran irisan, serta fungsi dari batu piring yang hasilkan. Batu piring yang memiliki kualitas baik dapat dijual dengan kisaran harga mulai $\mathrm{Rp} 45.000$ hingga $\mathrm{Rp} 80.000$, sedangkan batu piring yang digunakan untuk hiasan seperti hiasan kamar mandi hanya memiliki harga berkisar antara Rp 2.500 hingga Rp 10.000. Batu piring yang dihasilkan di 
Dusun Krajan II adalah batu piring yang banyak digunakan sebagai Furniture dan bahan bangunan. ${ }^{2}$

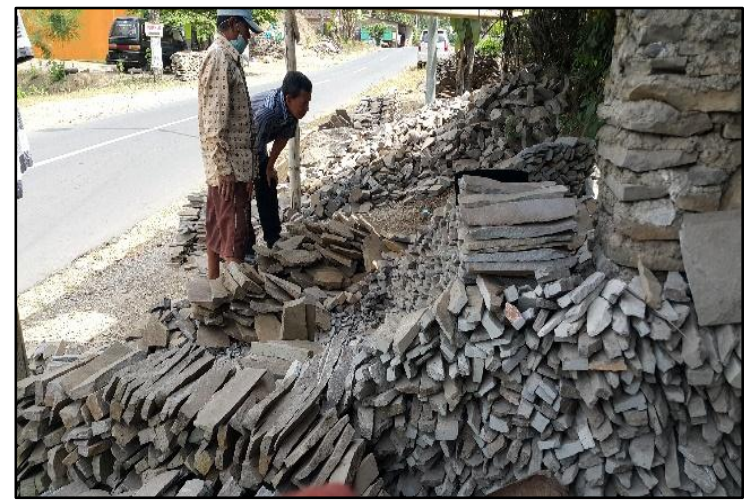

(a) Bentuk Batu Piring yang Dihasilkan Ukurannya Tidak Standar

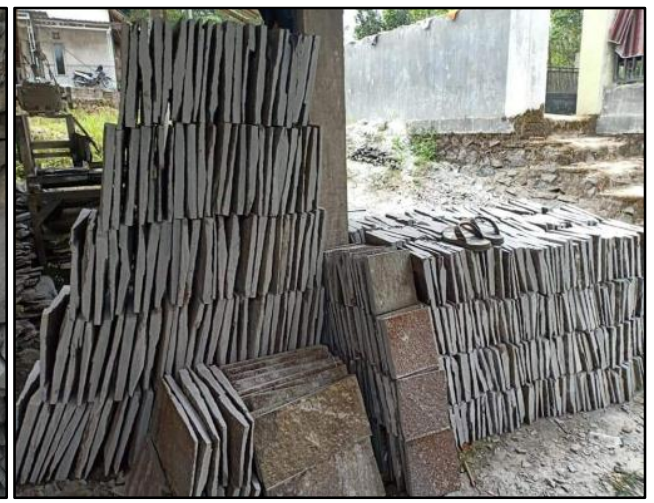

(b) Bentuk Batu Piring yang Dihasilkan Ukurannya Standar

\section{Gambar 2. Perbandingan Batu Piring yang Dihasilkan Secara Manual VS Batu Piring yang Dipotong dengan Menggunakan Mesin} (Sumber: Data Primer, 2020)

Salah satu pengusaha kerajian batu piring di Dusun Krajan II Desa Sukowiryo yaitu Pak Abdulla yang telah memiliki buruh pengrajin sebanyak 5 orang. Meski usaha kerajinan batu piring yang dilakukan oleh Pak Abdulla telah memiliki 5 orang buruh kerja, namun tingkat produktivitas dari usahanya tersebut masih tergolong rendah karena metode produksi yang dilakukan masih menggunakan peralatan yang manual, sehingga dalam proses produksi yang dilakukan membutuhkan waktu yang lebih lama bila dibanding menggunakan mesin pemotong. Hal inilah yang menjadi permasalahan Mitra, yaitu: 1) rendahnya tingkat produksi yang disebabkan oleh kurang efisiennya waktu dalam proses produksi; 2) biaya yang dibutuhkan untuk membeli mesin pemotong batu piring (Stone Cutter) relatif mahal, berkisar antara Rp 15.000.000 - Rp 20.000.000, bergantung pada ukuran mesin, sehingga tidak memungkinkan bagi Pak Abdulla untuk membeli alat tersebut. Proses produksi yang dilakukan secara manual juga membuat hasil produksi batu

2 Pemerintah Desa Sukowiryo Kecamatan Jelbuk Kabupaten Jember, 2020.

Peningkatan Skill Productivity Bagi Pengrajin Batu Piring di Desa Sukowiryo

Kecamatan Jelbuk Kabupaten Jember

Lilis Yuliati, Siti Komariyah, Sudarsono 
piring yang dihasilkan kurang terstandarisasi baik dari segi bentuk maupun ukuran yang dihasilkan.

Oleh karena itu, dengan potensi pasar yang dimiliki oleh produk Batu piring dan dengan keterbatasan peralatan yang digunakan dalam proses produksi kerajinan batu piring yang dilakukan oleh mitra yaitu Pak Abdulla maka tim pelaksana PPK memfasilitasi untuk meningkatkan skill productivity dengan memberikan bantuan alat produksi berupa mesin pemotong batu piring yang telah di modifikasi guna meningkatkan efisiensi waktu dan juga meningkatkan produktifitas pengerajin Batu Piring.

\section{Metode}

Tujuan dari program pengabdian kepada msyarakat PPK ini yaitu utuk meningakatkan skill productivity pada pengerajin batu piring di desa Sukowiryo Kecamatan Jelbuk Kabupaten Jember. Oleh karena itu, untuk merealisasikan program PPK tersebut diperlukan metode pelaksanaan sebagai berikut:

1. Guna melaksanakan program PPK dan dapat mencapai target dan sasaran program secara optimal, maka target atau mitra dalam program PPK ini yaitu pengusaha kerajiann batu piring yang memiliki 5 orang pekerja di Desa Sukowiryo Kecamatan Jelbuk Kabupaten Jember yaitu Pak Abdulla.

2. Mengingat keterbatasan dana pada program PPK ini, maka bantuan alat produksi berupa mesin pemotong batu piring guna meningkatkan skill productivity merupakan mesin bekas pakai yang di dimodifikasi dan dalam kondisi yang masih layak pakai serta dapat digunakan dalam jangka panjang.

3. Pemberian bantuan berupa mesin pemotong batu piring diharapkan mitra dapat meningkatkan produktifitasnya karena adanya efisiensi waktu dalam proses produksi dan juga dapat menambah jenis diversifikasi produk kerajinan batu piring yang dihasilkan. 
Oleh karena itu, tim pelaksana memberikan pendampingan dan monitoring kepada mitra dalam proses penciptaan alat pemotong batu piring yang dimodifikasi sesuai dengan kebutuhan mitra. Dalam proses pelaksanaannya, pendampingan dan bantuan yang diberikan kepada mitra tidak hanya dalam bentuk pemberikan bantuan berupa mesin pemtong batu piring saja melainkan fasilitas pendukung lainnya seperti salutan air untuk pembuangan dan penampungan air yang digunakan dalam proses memotong batu piring dengan menggunakan mesin, dan juga bantuan berupa pemasangan tambahan daya listrik yang ada di rumah mitra sebagai sumber dari listrik yang akn diguankan dalam proses produksi. Bantuan penambahan daya listrik di rumah mitra diberikan karena daya listrik yang ada di rumah mitra tidak mencukupi untuk mengoperasikan mesin pemotong batu piring, sehingga bantuan berupa penambahan daya listrik juag dilakukan untuk merealisasikan program PPK yang telah diajukan.

\section{Hasil dan Diskusi}

Hasil dan diskusi dari pelaksanaan program pengabdian kepada msyarakat PPK yaitu sebagai beriku:

\section{Proses Modifikasi dan pemasangan Mesin Pemotong Batu Piring}

Pada usulan program PPK ini mengajukan untuk emberikan bantuan kepada mitra yaitu Pak Abdulla yang memiliki usaha kerajinan Batu Piring di Desa Sukowiryo Kecamatan Jelbuk berupa alat pemotong batu piring dengan tujuan untuk meningkatkan produktifitas Pak Abdulla untuk memproduksi Batu piring dengan cara melakukan modifikasi atal pemotong batu piring, sehingga biaya yang dibutuhkan untuk membuat hingga memasang bantuan alat tersebut dapat ditekan atau dengan biayay yang lebih kecil. Adapun alat atau mesin yang digunakan dalam bantuan ini merupakan mesin yang bekas pakai sehingga harga mesin tersebut lebih rendah dibandingkan dengan mesin yang masih baru, namun dalam hal ini timbersama mitra memilih mesin yang masih memiliki kondisi dan

Peningkatan Skill Productivity Bagi Pengrajin Batu Piring di Desa Sukowiryo 
performa yang masih baik sehingga masih dapat digunakan dalam jangka panjang. Selain pembelian mesin, untuk memodifikasi alat pemotong batu piring juga perlu dilakukan service pada alat yang telah dibeli untuk memastikan kondisi dan performa dari mesin tersebut tidak jauh berbeda dengan mesin yang baru. Selanjutnya itu dibangun kerangka meja untuk memasang alat pemotong batu piring sesuai dengan kebutuhan mitra. Berikut merupakan bentuk kerangka meja pemotong batu piring yang telah disepakati oleh mitra.

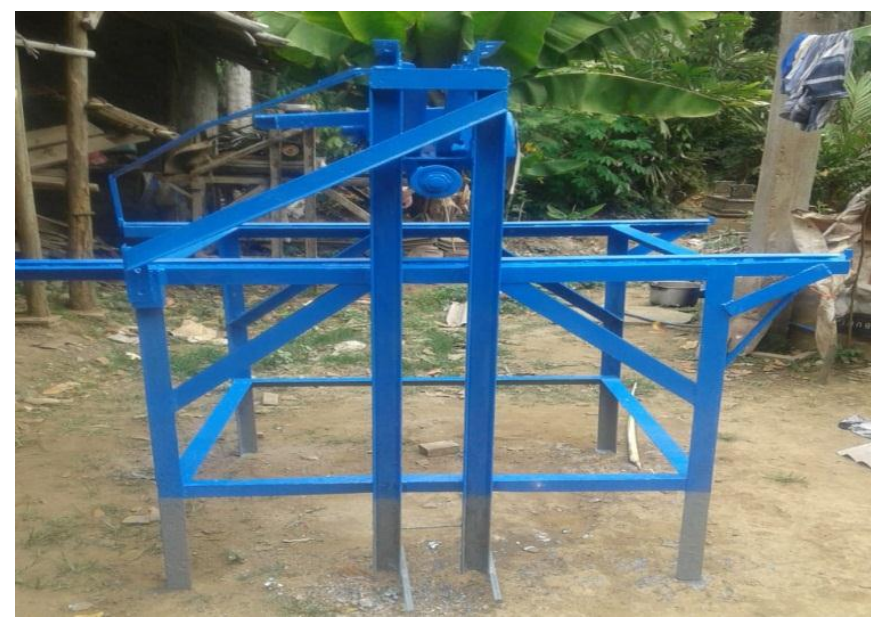

\section{Gambar 3. Kerangka Meja yang Akan Dipasangkan alat Pemotong Batu Piring (Sumber: Bengkel Las Bubut NTK)}

Gambar 3. merupakan kerangka meja yang akan dipasangkan alat pemotong batu piring dan juga saluran kecil air yang akan digunakan dalam proses pemotongan batu piring. Tujuan dari dipasangkannya saluran kecil air pada mesin tersebut yaitu untuk meminimalisir debu dan pecahan batu pada saat proses pemotongan, selain itu, hasil dari pemotongan batu yang dialiri oleh air juga lebih baik karena bentuk dari batu tersebut dapat dilihat dengan jelas pada saat proses pemotongan. Selanjutnya, setelah melakukan pemasangan mesin dan juga saluran kecil air, mitra juga memerlukan sistim saluran pembuangan dan penampungan 
air yang akan digunakan untuk kegiatan produksinya, oleh karena itu, tim juga memberikan bantuan untuk memasang dan mendesain sistim saluran air yang akan digunakan.

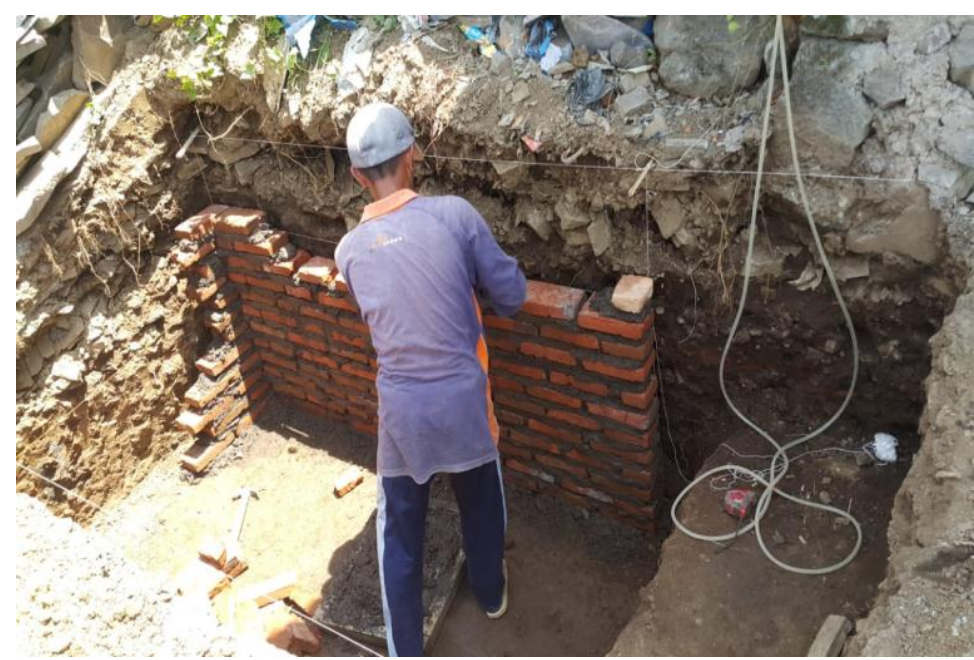

\section{Gambar 4. Pembangunan Saluran Pembuangan Dan Penampungan Air (Sumber: Dokumentasi Lapangan, 2020)}

Gambar 4. menunjukkan proses pembangunan penampungan air dan juga saluran pembuangan air yang akan digunakan oleh Pak Abdulla dalam kegiatan produksi atau dalam melakukan pemotongan batu piring. Penggunaan air dalam proses produksi tersebut tidak dilakukan untuk sekali pakai karena untuk menghemat biaya produksi, maka air yang dialirkan kemesin pemotong batu piring bersumber dari bak penampungan air, dan nantinya bekas air yang mengalir dari mesin pemotong batu piring juga akan dialirkan kembali ke bak penampungan air. Setelah pembangunan penampungan air dan saluran pembuangan air selesai dan siap digunakan, mesin pemotong batu piring yang telah di modifikasi sebelunya baru di serahkan ke Pak Abdulla dan di pasang di tempat usahanya. Selain menyerahkan mesik kepada mitra juga dilakukan tandatangan serah terima bantuan mesin pemotong batu piring kepada 
mitra sebagai bukti telaksananya kegiatan pengabdian PPP yang telah diusulkan.

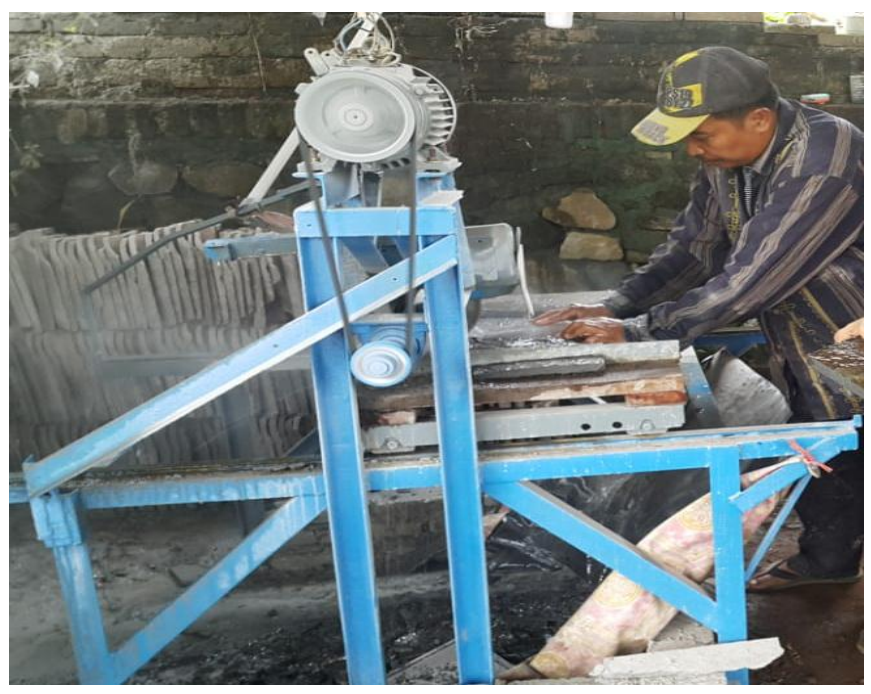

\section{Gambar 5. Bentuk Mesin Pemotong Batu Piring Yang Telah Di Modifikasi Dan Diserahkan Kepada Mitra (Sumber: Dokumentasi Lapangan, 2020)}

Setelah dilakukan serah terima, dan pemasangan alat pemotong batu piring, mesin pemotong tersebut belum siap digunakan untuk melakukan produksi karena kekuatan atau daya listrik yang terpasang di rumahnya Pak Abdulla tidak mencukupi untuk digunakan dalam kegiatan produksi. Oleh karena itu, tim juga memberikan bantuan penambahan daya kepada mitra. Sehingga dengan bertambahnya daya yang terpasang di rumahnya Pak Abdulla diharapkan mesin tersebut segera dapat digunakan Pak Abdulla untuk memproduksi kerajinan batu piring dan meningkatkan produktifitasnya. 


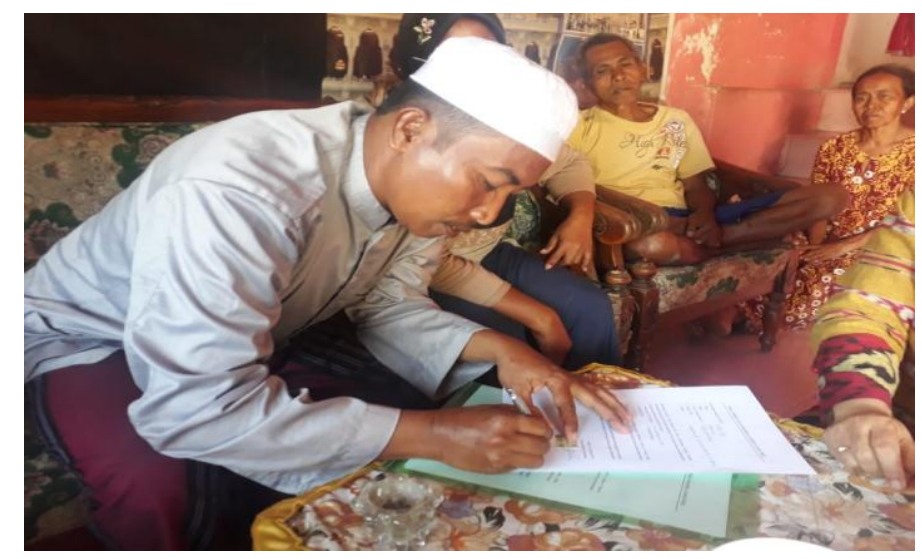

Gambar 6. Tanda Tangan Serah Terima Bantuan Mesin Pemotong Batu Piring Kepada Mitra (Sumber: Dokumentasi Lapangan, 2020)
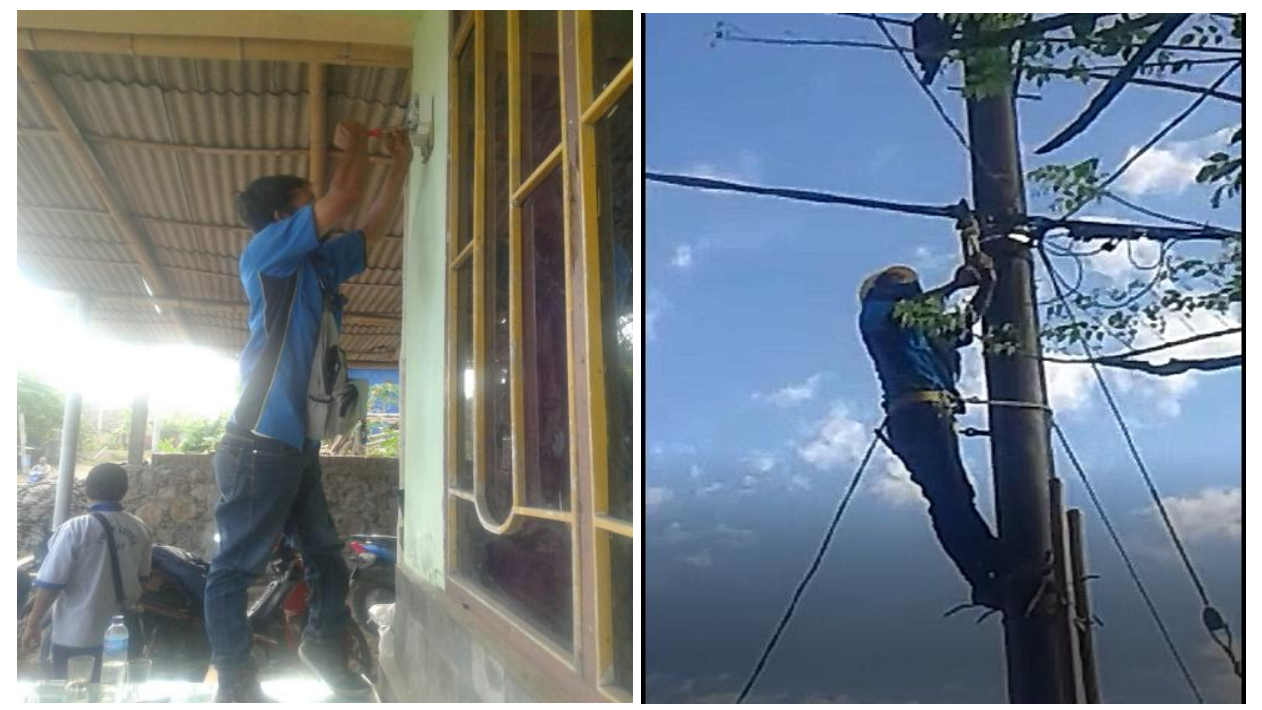

Gambar 7. Proses Penambahan Daya Listrik Di Rumah Mitra Sebagai Sumber Listrik Dalam Kegiatan Produksi Yang Dilakukan Oleh Mitra (Sumber: Dokumentasi Lapangan, 2020)

Setelah dilakukan pemasangan dan penambahan daya listrik di rumah Pak Abdulla maka mesin yang telah dipasang siap untuk digunakan dalam proses produksi kerajinan Batu Piring. Berikut merupakan gambaran proses pemberian bantuan berupa penambahan daya yang dilakukan di rumah Pak Abdulla. 


\section{Proses Produksi Kerajinan Batu Piring di Desa Sukowiryo Kecamatan} Jelbuk Kabupaten Jember dengan Mengunakan Alat Pemotong Batu Piring.

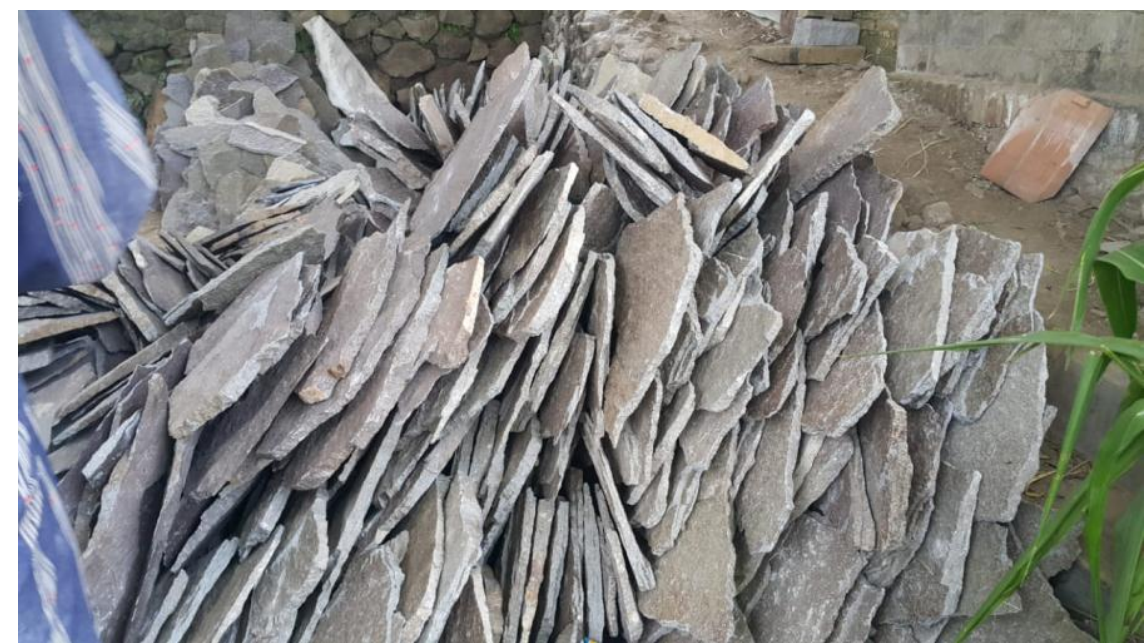

\section{Gambar 8. Batu Piring Yang Belum Diolah Oleh Pengerajin Batu Piring (Sumber: Dokumentasi Lapangan, 2020)}

Gambar 8. menunjukkan kondisi batu piring mentah yang diproleh dari pihak penambang batu piring. Pada Gambar 8. juga dapat dilihat bahwa kondisi batu piring mentah yang diperoleh oleh mitra memiliki ukuran dan bentuk yang berbeda-beda. Bahan batu piring mentah yang digunakan oleh mitra diperoleh dari penambangan batu piring yang ada di wiayah sekitar di Kecamatan Jelbuk dan Kecamatan Kalisat. Sehingga perolehan faktor produksi berupa batu pirng mentah cenderung mudah didapatkan oleh mitra dan membutuhkan biaya faktor produksi yang lebih kecil karena jarak anatara tempat produksi dan sumber faktor produksi yang relatif dekat.

Kemudian, setelah dilakukannya pemasangan dan penambahan daya, mesin pemotong batu piring yang telah dimodifikasi siap untuk di gunakan dalam proses produksi terta dapat meningkatkan produktifitas dari mitra. Batu-batu yang di dapat dari penambangan selanjutnya akan 
dipotong semenarik mungkin, untuk batu yang digunakan sebagai lantai akan di potong berbentuk kotak-kotak dan dijual dengan harga per-meter. Sementara untuk batu piring yang digunakan sebagai furniture dinding akan dipotong abstrak dengan mempertahankan tekstur alami batu dan dijual dengan harga per-ton. Berikut merupakan prose pemotongan batu piring yang dilakukan secara langsung oleh Pak Abdulla dengan menggunakan mesin yang telah dimodifikasi sebelumnya.

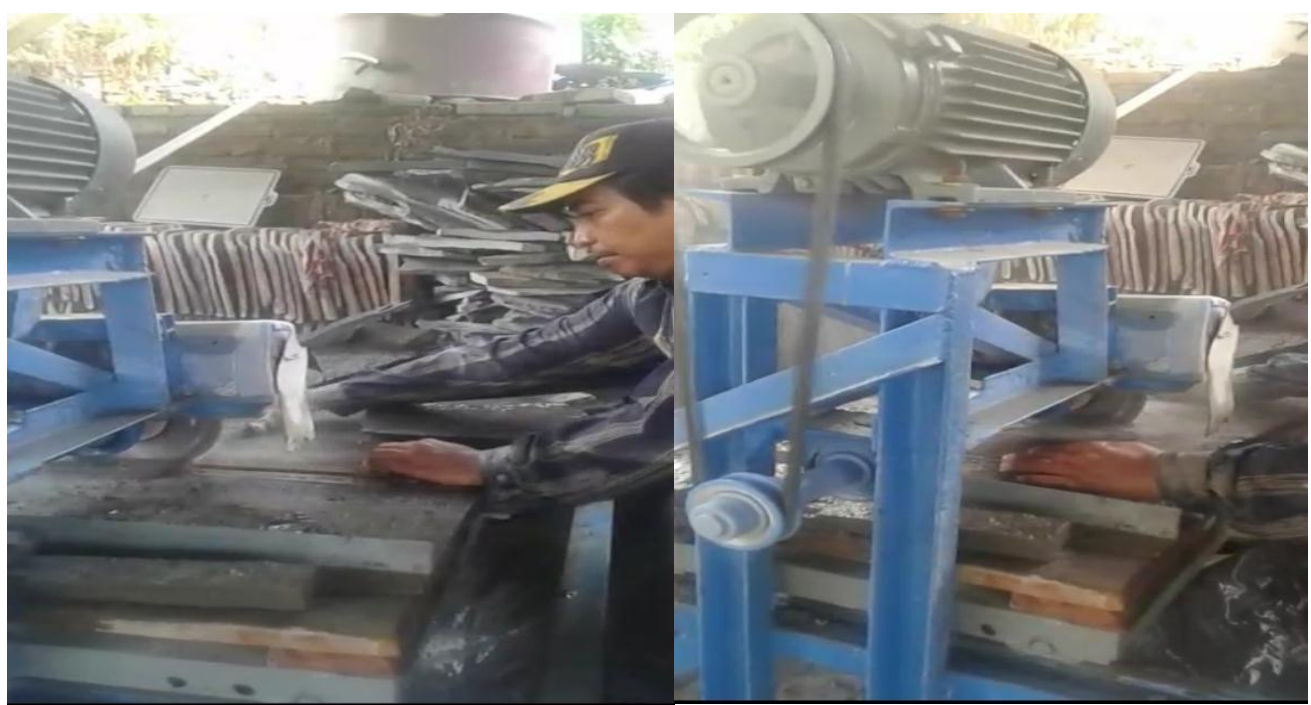

Gambar 9. Proses Pemotongan Batu Menggunakan Alat Yang Telah Di Modifikasi (Sumber: Dokumentasi Lapangan, 2020)

Gambar 9. menunjukkan proses pemotongan batu piring dengan menggunakan mesin yang telah dimodifikasi. Proses produksi yang dilakukan oleh mitra dengan menggunakan mesin yang telah dimodifikasi, mitra dapat melakukan efisiensi dan juga efektifitas terutama dalam hal waktu. Selain itu, mitra juga dapat meningkatkan hasil produktifitasnya serta meningkatkan kualitas dari produk kerajinan batu piring yang dihasilkan oleh mitra. Sebagaimana yang ditunjukkan dalam Gambar 10.

Pada Gambar 10. dapat dilihat bahwa hasil produksi dari kerajinan Batu Piring yang dilakukan dengan mengguankan mesin lebih terstandarisasi 
dan juga lebih rapi, adapun produk yang di hasilkan oleh mitra yaitu Batu pirirng yang digunakan untuk Lantai dan Batu Piring yang digunakan sebagai hiasan dinding.

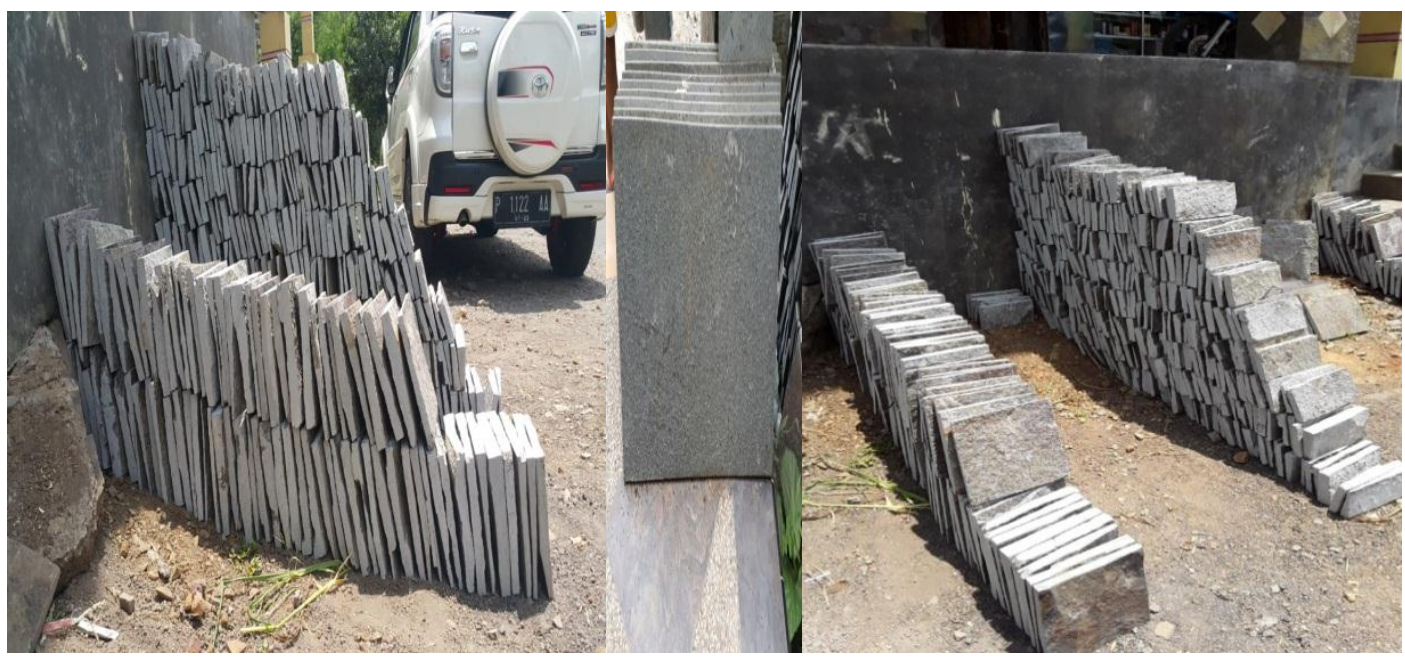

Gambar 10. Hasil Produksi Kerajinan Batu Piring dengan Menggunakan alat Pemotong Batu Piring (Sumber: Dokumentasi Lapangan, 2020)

Gambar 10. menunjukkan hasil produksi mitra yaitu kerajinan batu piring berupa lantai dan hiasan untuk dinding setelah menggunakan mesin pemotong batu piring. Sebelum memperoleh bantuan berupa alat pemotong batu piring, mitra masih belum bisa memproduksi kejarinan batu piring yang berupa lantai karena kerajinan tersebut harus memiliki ukuran lebar dan ketebalan yang sama, sehingga sebagain besar hasil produksi yang dihasilkan oleh mitra sebelum memperoleh bantuan hanya berupa hiasan dinding dengan berbagai macam ukuran dan model yang dpaat dihasilkan dengan alat yang manual, dan hal tersebut membutuhkan waktu yang lebih lama.

Setelah mitra memperoleh bantuan mesin pemotong batu piring dari tim, mitra tidak hanya dapat memproduksi kerajinan batu piring berupa hiasan dinding, tetapi juga dalam banetuk lantai. Hal ini menunjukkan bahwa dengan adanya bantuan mesin pemotong batu piirng mitra juga 
dapat menambah difersifikasi produk yang dihasilkan. Selain itu, mitra juga dapat melakukan efisiensi waktu produksi karena dengan menggunakan mesin pemotong batu piring proses produksi jadi lebih mudah dan membutuhkan waktu yang jauh lebih singkat. Oleh karena itu, dengan adanya efisiensi waktu dalam proses produksi, mitra juga dapat meningkatkan produktifitasnya dalam menghasilkan kerajinan Batu Piring. Selain itu sisa dari potongan batu piring yang dihasilkan oleh mitra juga diolah kembali menjadi batu koral sehingga secara keseluruhan bahan batu piring yang diperoleh dan diolah oleh mitra memiliki nilai ekonomis. Proses pengolahan batu koral yang dilakukan oleh mitra masih menggunakan alat yang sederhana atau alat manual berupa palu seperti yang di tunjukkan dalam Gambar 11 sebagai berikut.

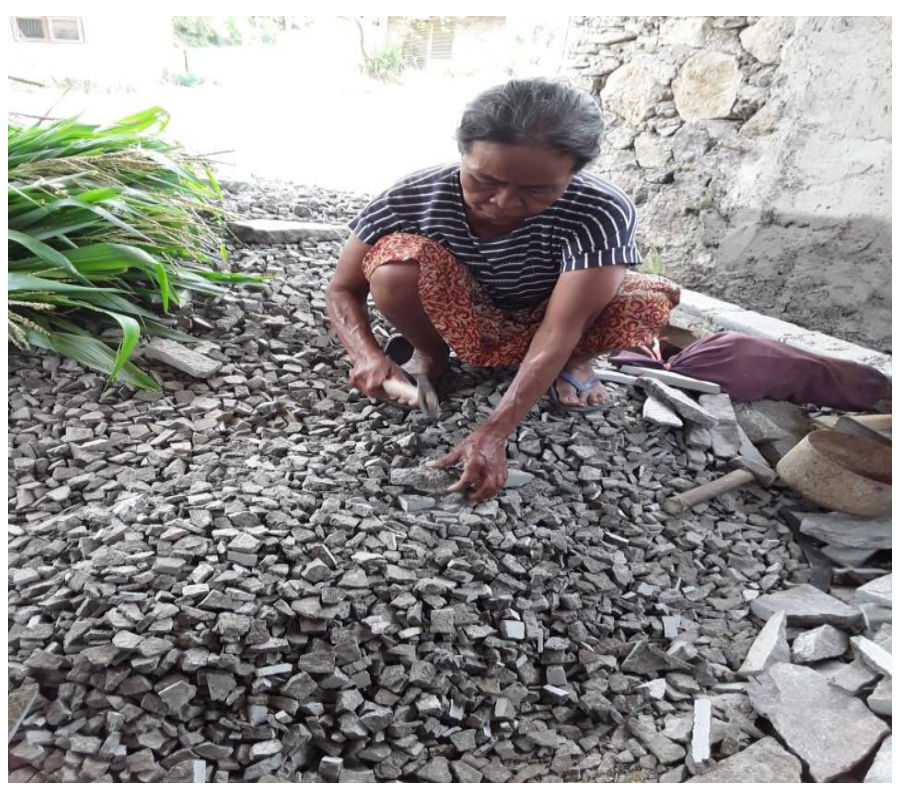

Gambar 11. Proses Produksi Batu Koral dari Sisa Pemotongan Batu Piring (Sumber: Dokumentasi Lapangan, 2020) 


\section{Simpulan}

Proses Produksi kerajinan batu piring yang dilakukan oleh pihak Mitra yaitu Pak Abdulla saat ini tidak hanya menggunakan alat yang sederhana atau alat manual tetpai juga dengan mesin. Dengan adanya bantuan mesin pemotong batu piring yang diberikan olem PPK, mitra dapat menambah diversifikasi hasil produksi kerajinan batu piring berupa produksi lantai dari batu piring. Selain itu, hasil produksi kerajinan batu piring yang dihasilkan oleh mitra juga lebih terstandarisasi dan memiliki kualitas produk yang lebih baik. Tidak hanya itu, mitra juga dapat melakukan efisiensi waktu produksi dan meningatkan hasil produksinya dengan adanya bantuan mesin pemotong batu piring dan penambahan daya listrik di rumah mitra. Secara keseluruhan bahan batu piring yangd iperoleh oleh mitra dapat diproduksi secara keseluruhan dengan berbagai diversifikasi produk dan nilai produk yang bervariasi. Sehingga seluruh bahan batu piring yang digunakan, hampir secara keseluruhan digunakan dan dapat diolah menjadi hasil kerjinan dan memiliki nilai ekonomis

\section{Daftar Referensi}

Bengkel Las Bubut TNK. Gambar Mesin Pemotong Batu Piring. https://www.bengkelntk.com/2016/07/jual-mesin-pemotong-batupisau-24-type.html. Diakses 11 Maret 2020. Pukul 12.45.

Pemdes Sukowiryo. Profil Desa Sukowiryo. https://desasukowiryoweb.wordpress.com/profil-desa-2/ . Diakses 10 Maret 2020. Pukul 19.00

Pemdes Sukowiryo. Potensi Desa Sukowiryo. https://desasukowiryoweb.wordpress.com/profil-desa-2/ . Diakses 10 Maret 2020. Pukul 19.00 